\title{
Effect of mechanical activation of fly ash added to Moroccan Portland cement
}

\author{
H. Ez-zaki ${ }^{1 *}$, A. Diouri ${ }^{1}$, M. Maher ${ }^{2}$, A. Aidi ${ }^{2}$ and T. Guedira ${ }^{2}$ \\ ${ }^{1}$ Laboratoire de Chimie du Solide Appliquée (LCSA), Mohammed V University, Rabat, Morocco \\ ${ }^{2}$ Laboratoire de matériaux, électrochimie et environnement, Ibn Tofail University, Kenitra, Morocco \\ *Corresponding Author: ezzaki86@gmail.com
}

\begin{abstract}
Nowadays, the cement industry is the largest emitter of $\mathrm{CO}_{2}$. In 2015, cement production accounts for roughly $8 \%$ of global $\mathrm{CO}_{2}$ emissions. In order to reduce this impact, cement plants are working on alternative solutions, for instance, producing cement by adding additives like fly ash known for reducing the emissions of $\mathrm{CO}_{2}$ and minimizing production costs. The thermal power stations in Morocco produce more than 500000 tons per year. For ecological and sustainable development reasons, it is desirable to recycle these quantities according to beneficial methods to their addition in the cement.

This study aims to investigate the influence of grinding fly ash on the physico-chemical and mechanical properties of fly ash blended CPJ45 cement. The addition of the fly ash particles to the grinder leads respectively to the breakage of the particles and to reduce the agglomeration effect in the balls of cement grinder. Fly ash milling was found to improve particles fineness, and increase the silica and alumina content in the cement. Furthermore, milled fly ash blended cements show higher compressive strength compared to unmilled fly ash blended cements, due to improved fly ash reactivity through their mechanical activation.
\end{abstract}

\section{Introduction}

The cement industry is one of the industries that release a significant amount of greenhouse gases. According to the World Business Council for Sustainable Development (WBCSD) [1], emissions from Portland cement manufacturing vary in different regions of the world from 0.73 to $0.99 \mathrm{~kg}$ of $\mathrm{CO}_{2}$ per $\mathrm{kg}$ of cement produced [1]. The main sources of carbon dioxide in cement manufacturing are combustion of fossil fuel and limestone calcinations. During the clinkering process, limestone will undergo calcination and $\mathrm{CO}_{2}$ will be released [2].

With the aim of alleviating their $\mathrm{CO}_{2}$ emissions, cement manufacturers have implemented new alternatives as adding fly ash to cement. Fly ash is a by-product of the combustion of pulverized coal in thermal power plants. The dust collection system removes fly ash, as a fine particulate residue, from the combustion gases before they are discharged into atmosphere. Most of the fly ash particles are solid spheres; the average particle size is about $10 \mu \mathrm{m}$ but can vary from less than $1 \mu \mathrm{m}$ to over than $150 \mu \mathrm{m}[3,4]$. Fly ash is entirely composed of silica, alumina, iron and calcium. The magnesium, sulphur, sodium, potassium and carbon are minor constituents [3, 5-7]. The reactive part of fly ash is their amorphous phase which is composed mainly of silicon [8]. When mixed with Portland cement and water, fly ash induces a reaction with the calcium hydroxide released by the hydration of Portland cement to produce calcium-silicate hydrates (CSH) [9-13]. However, there are few limitations of the use of fly ash in cement because of the late pozzolanic reaction that starts only after 7 to 28 days [14-16]. Therefore, several authors have conducted studies on how to activate fly ash trough milling $[5,17$, 18]. Kocak et al. [19] reported that the use of fly ash without mechanical activation decreases the compressive strength of blended cements for all fly ash addition rates $(5,10,15,20$ and $25 \%)$ compared to the reference value. However, the authors noticed an improved mechanical strength even below the reference indicating activation of pozzolanic reactions at a high curing time [19]. Mechanical activation of fly ash was conducted by Chen et al. [18] to treat fly ash from a municipal solid waste incinerator. The authors found that the replacement of less than $10 \%$.wt. of the cement by this activated fly ash leads to a slight improvement of the cement strength. Krishnaraj et al [20] have studied the effect of the replacement of ordinary Portland cement with up to 60 $\%$.wt. of unmilled and milled fly ash in mortar preparation. Results have shown that the replacement of the cement by an amount larger than $15 \%$.wt. can increase the compressive strength at only 28 days of 
curing if milled fly ash is used as an addition instead of unmilled fly ash.

In this study, we highlight the effect of mechanical activation of fly ash on the physico-chemical and mechanical properties of fly ash blended Portland cement. An experimental evaluation on the addition of unmilled (UMFA) and milled fly ash (MFA) to the CPJ45 cement was achieved.

\section{Materials and method}

\subsection{Materials}

Two materials were used in this study, an industrial CPJ45 cement and fly ash (FA). The milling of FA was achieved using a vibratory disc mill oscillating for 3 minutes. The physical characteristics of the materials were investigated using an Alpine sieve to determine the refusal at 45 and $80 \mu \mathrm{m}$ sieves, and the ethylene glycol method to estimate the amount of free lime. The chemical composition of the cement, unmilled and milled FA was performed using X-ray fluorescence spectroscopy. The results are reported in Table 1.

Table 1. Physical and chemical properties of Portland cement, unmilled and milled fly ash (wt.\%).

\begin{tabular}{|c|c|c|c|}
\hline$(w t \%)$ & CPJ45 & Unmilled FA & Milled FA \\
\hline $\mathrm{SiO}_{2}$ & 18,4 & 48,93 & 49,38 \\
\hline $\mathrm{Al}_{2} \mathrm{O}_{3}$ & 4,65 & 25,49 & 26,61 \\
\hline $\mathrm{Fe}_{2} \mathrm{O}_{3}$ & 2,85 & 5,11 & 5,22 \\
\hline $\mathrm{CaO}$ & 55,35 & 7,03 & 5,76 \\
\hline $\mathrm{MgO}$ & 1,84 & 2,37 & 2,31 \\
\hline $\mathrm{SO}_{3}$ & 2,01 & 0,28 & 0,13 \\
\hline $\mathrm{K}_{2} \mathrm{O}$ & 0,78 & 2,18 & 2,11 \\
\hline $\mathrm{TiO}_{2}$ & 0,28 & 1,15 & 1,19 \\
\hline $\mathrm{MnO}$ & 0,07 & 0,08 & 0,08 \\
\hline $\mathrm{P}_{2} \mathrm{O}_{5}$ & 0,13 & 0,70 & 0,76 \\
\hline L.O.I* & 13,51 & 6,31 & 6,10 \\
\hline F.L** & 1,68 & - & - \\
\hline $\begin{array}{l}\text { Rf } * * *: \\
45 \mu \mathrm{m} \\
80 \mu \mathrm{m}\end{array}$ & $\begin{array}{l}7,3 \\
0,7\end{array}$ & $\begin{array}{l}31,2 \\
17,3\end{array}$ & $\begin{array}{l}8,6 \\
0,6\end{array}$ \\
\hline
\end{tabular}

The X-ray diffraction analysis of FA was carried out in order to determine its mineralogical composition. The $\mathrm{X}$-ray diffractogram is shown in Figure 1. From the X-ray diffractogram, it can be seen that quartz and mullite make up the majority of crystalline phases in the used FA.
The XRF and XRD results can show that the FA contains a large amount of $\mathrm{SiO}_{2}, \mathrm{Al}_{2} \mathrm{O}_{3}, \mathrm{Fe}_{2} \mathrm{O}_{3}$, while the content of $\mathrm{CaO}$ is poor. This allows us to classify these ashes into class $\mathrm{F}$ known as silicoaluminous according to ASTM C 618 specification [21]. The presence of an amorphous halo, located between $21^{\circ}$ and $31^{\circ}$ in $2 \theta$, indicates the presence of a glassy phase in the used FA [22].

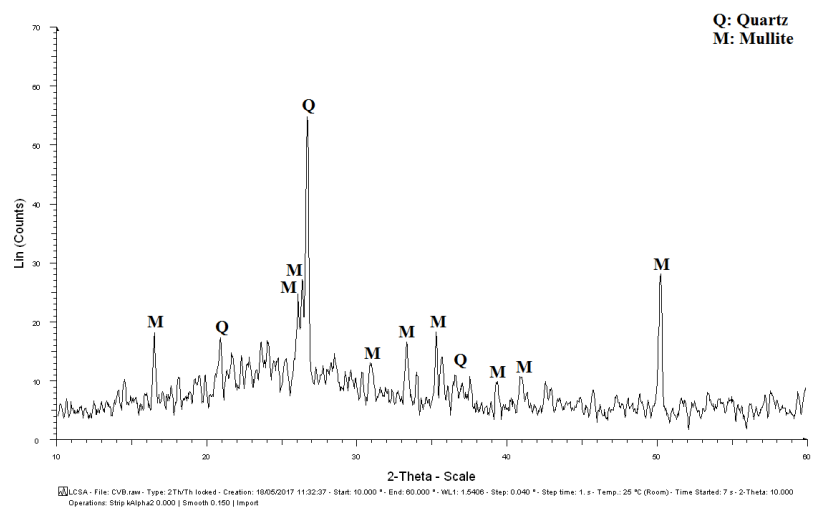

Fig.1. XRD pattern of milled fly ash.

\subsection{Method}

The addition method consists of introducing $1 \mathrm{~kg}$ of industrial cement and fly ash, with different percentages (5, 10 and 20 wt.\%), into a plastic bag, then mixed manually for one hour until the mixture became homogeneous. The first series of samples were prepared by mixing the cement with unmilled fly ash. Three blended cements were prepared and noted $\left(\mathrm{C}_{\mathrm{UM}}\right)$. The second series of samples were made by mixing the cement with milled fly ash. The used designations of the three blended cements were $\left(\mathrm{C}_{\mathrm{M}}\right)$. These six samples were tested and compared to the reference industrial CPJ45 cement, noted $\mathrm{C}_{0}$. The proportions of prepared composed cements are shown in Table 2.

Table 2. Composition of blended cements.

\begin{tabular}{ccc}
\hline Samples & CPJ45 (g) & FA (g) \\
\hline $\mathrm{C}_{0}$ & 1000 & 0 \\
$5 \mathrm{C}_{\mathrm{UM}}$ & 950 & 50 \\
$10 \mathrm{C}_{\mathrm{UM}}$ & 900 & 100 \\
$20 \mathrm{C}_{\mathrm{UM}}$ & 800 & 200 \\
$5 \mathrm{C}_{\mathrm{M}}$ & 950 & 50 \\
$10 \mathrm{C}_{\mathrm{M}}$ & 900 & 100 \\
$20 \mathrm{C}_{\mathrm{M}}$ & 800 & 200 \\
\hline
\end{tabular}

The refusal, the amount of free lime and the chemical composition of the samples were determined using the same methods mentioned above.

Mortars were prepared by mixing one part of cement and three parts of standard sand with water/cement ratio $\mathrm{W} / \mathrm{C}=0.5$. The mortar mixtures were then casted in oiled moulds $4 \times 4 \times 16 \mathrm{~cm}$ and packed with 
the shock apparatus. Afterwards, the specimens were stored in a moisture room at $20 \pm 1^{\circ} \mathrm{C}$ and relative humidity of $\geq 90^{\circ} \mathrm{C}$. Samples were demoulded after $24 \mathrm{~h}$ and then cured in water until the days of mechanical determinations (2, 7 and 28 days).

\section{Results and discussion}

\subsection{Physical and chemical characteristics}

The physical and chemical characteristics of the tested samples are shown in Table 3. The content of $\mathrm{SiO}_{2}$, $\mathrm{Al}_{2} \mathrm{O}_{3}$ and $\mathrm{Fe}_{2} \mathrm{O}_{3}$ increases proportionally with the increase of fly ash addition. This is due to their high content in the FA used in this study. Contrarily, the low content of $\mathrm{CaO}$ in the FA conducts to a decrease of this oxide in the blended cements. Free lime content increases when adding $5 \%$ of unmilled or milled FA to the cement, and decreases bellow the reference value for higher adding values of 10 and $20 \%$. However, the loss on ignition decreases bellows the reference value (Table 1) for all additions; unmilled and milled. When unmilled FA was added to the cement, the refusal increased reaching $12.2 \%$ and $3.6 \%$ for 45 and $80 \mu \mathrm{m}$ sieves respectively. This increase was also noticed when different percentages (3, 5, 7 and $10 \%)$ of unmilled FA were added to the cement [23]. On the other hand, when the cement was blended with milled FA, the refusal of the samples was kept the same as the reference.

Table 3. Physical and chemical characteristics of the six tested samples.

\begin{tabular}{|c|ccc|ccc|}
\hline $\mathbf{( w t} \%)$ & $\mathbf{5 C}_{\mathbf{U M}}$ & $\mathbf{1 0 C}_{\mathbf{U M}}$ & $\mathbf{2 0 C}_{\mathbf{U M}}$ & $\mathbf{5} \mathbf{C}_{\mathbf{M}}$ & $\mathbf{1 0 C}_{\mathbf{M}}$ & $\mathbf{2 0 C}_{\mathbf{M}}$ \\
\hline $\mathrm{SiO}_{2}$ & 19.73 & 22.16 & 25.09 & 20.23 & 22.4 & 25.24 \\
$\mathrm{Al}_{2} \mathrm{O}_{3}$ & 5.51 & 7.03 & 9.34 & 5.39 & 7.29 & 9.35 \\
$\mathrm{Fe}_{2} \mathrm{O}_{3}$ & 3.02 & 3.2 & 3.34 & 2.93 & 3.4 & 3.36 \\
$\mathrm{CaO}$ & 53.7 & 50.07 & 45.41 & 52.15 & 49.14 & 45.32 \\
$\mathrm{MgO}$ & 1.86 & 1.95 & 1.95 & 1.85 & 2.2 & 1.99 \\
$\mathrm{SO}_{3}$ & 1.9 & 1.8 & 1.6 & 1.43 & 1.13 & 0.68 \\
$\mathrm{~K}_{2} \mathrm{O}$ & 0.84 & 0.95 & 1.05 & 0.83 & 0.91 & 1.06 \\
$\mathrm{TiO}_{2}$ & 0.3 & 0.37 & 0.46 & 0.32 & 0.45 & 0.47 \\
$\mathrm{MnO}$ & 0.08 & 0.08 & 0.08 & 0.08 & 0.08 & 0.08 \\
$\mathrm{P}_{2} \mathrm{O}_{5}$ & 0.16 & 0.2 & 0.26 & 0.17 & 0.22 & 0.26 \\
$\mathrm{L.O.I}$ & 13 & 12.82 & 12.29 & 13.09 & 12.9 & 12.09 \\
$\mathrm{~F} . \mathrm{L}$ & 1.73 & 1.56 & 1.37 & 1.7 & 1.54 & 1.42 \\
$\mathrm{Rf} .:$ & & & & & & \\
$45 \mu \mathrm{m}$ & 8.7 & 10 & 12.2 & 7.4 & 7.6 & 7.8 \\
$80 \mu \mathrm{m}$ & 1.4 & 2.3 & 3.6 & 0.7 & 0.7 & 0.8 \\
\hline
\end{tabular}

\subsection{Mechanical properties}

Mortars of the studied samples are tested with flexural and compressive tests after 2, 7 and 28 days of curing. The obtained results are summarized in Figure 2 and 3.
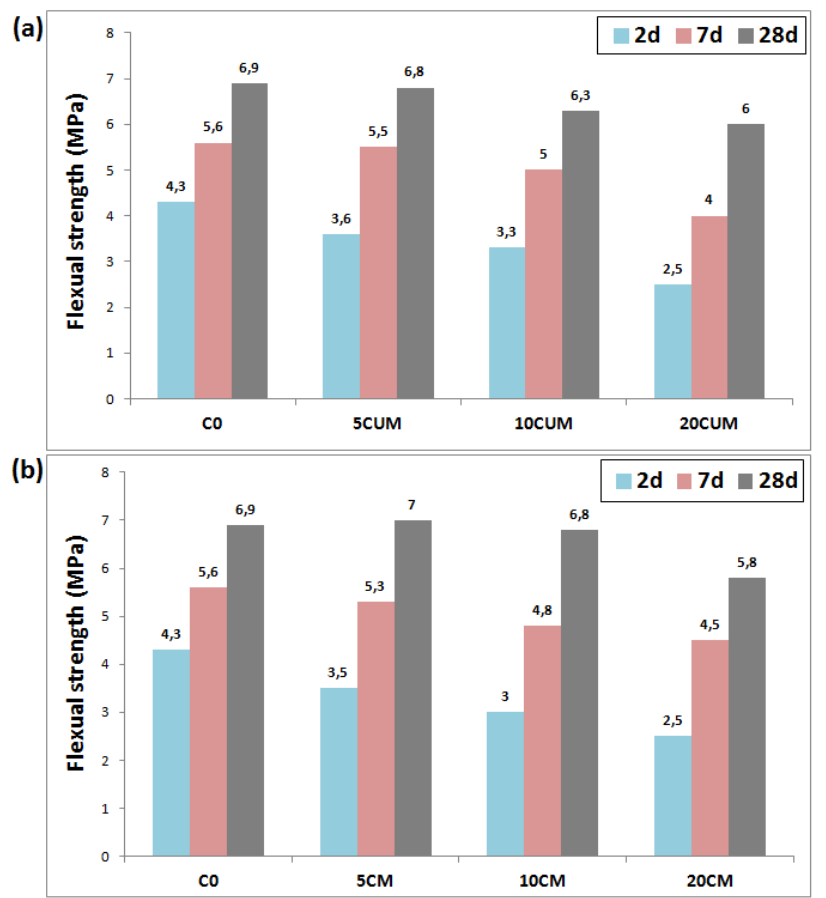

Fig.2. Evolution of flexural strength of

(a) UMFA cement mortars and (b) MFA cement mortars with curing age in comparison with control cement.

(a)

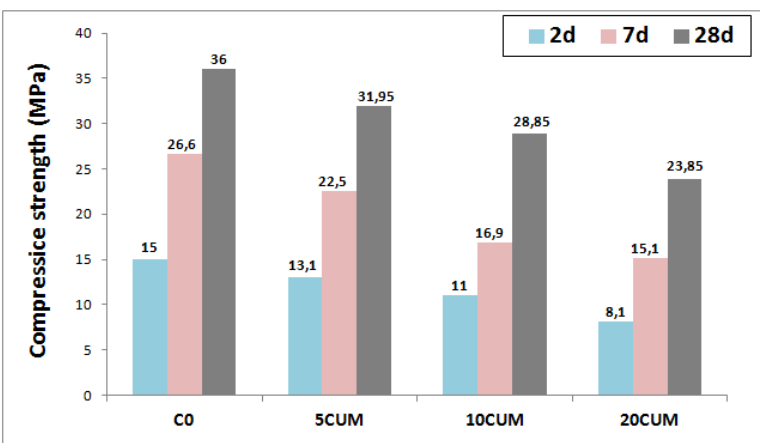

(b)

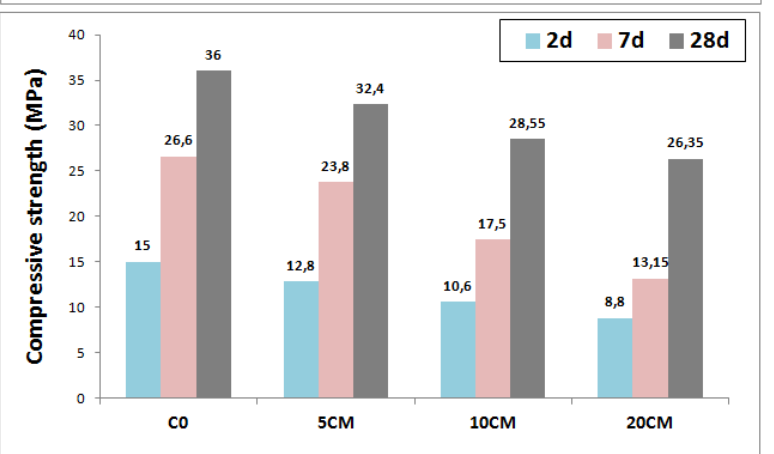

Fig.3. Evolution of compressive strength of (a) UMFA cement mortars and (b) MFA cement mortars with curing age in comparison with control cement.

The Figure 2 shows that flexural strength was affected by the addition of unmilled or milled FA except the mortar with $5 \%$ of MFA which displayed a similar 
value of the reference. Elkhadiri et al. [24] have also reported that the addition of various amounts of fly ash to the cement didn't have a significant effect on its flexural strength. Besides, the compressive strength decreases with the addition of fly ash (Figure 3 ). These results are in agreement with other studies [23,25], who found that the compressive strength decreases for additions of $5 \%$, $10 \%$ and $20 \%$ of fly ash, and goes below the cement control values at an addition rate of $7 \%$. This is due to the fact that class F fly ash is a slow reacting pozzolan, which means that it only starts to react noticeably after several weeks at $20^{\circ} \mathrm{C}$ of curing [26]. According to De Weerdt et al. [27], when fly ash is added to the cement, the amount of the principal reactive component of the cement, which is the clinker, decreases. This is known as the dilution effect. The filler effect of the FA can not compensate for the dilution effect at tested ages (2, 7 and 28 days), hence, the decrease in strength during early ages.

When the compressive strength values of mortars containing FA are compared, it can be noted that mortars made with MFA showed higher strength values than mortars with UMFA. This has also been noticed by $\mathrm{J}$. Payá et al. [28] who carried out a comparative study on the strength development of UMFA/MFA cement mortars, they found that MFA blended cements exhibit higher compressive strength compared to cement mixed with UMFA. They also noticed that greater compressive strength values were obtained for lower replacing percentages $(15 \%)$ and an increased FA grinding time (40 - $60 \mathrm{~min}$ ). However, these compressive strength values were bellow the value found for the control mortar containing Portland cement only. In the other hand, the compressive strength of cement mortars with FA milled for prolonged time exceeded the value of the control mortar at all ages, while the UMFA mortars showed a decrease in the compressive strength bellow the reference value $[10,29,30]$.

The Figure 3 -a shows that when $5 \%$ of UMFA is added, the value of the compressive strength at 28 days decreases from $36 \mathrm{MPa}$, value of the reference, to 31.95 $\mathrm{MPa}$, which means that it only reaches a relative mechanical strength of $88.75 \%$ of the control mortar value, and continues to decrease to reach $23.85 \mathrm{MPa}$ which corresponds to $20 \%$ of fly ash addition [31]. In the series of mortars made by mixing cement with MFA (Figure 3-b), the compressive strength at 28 days reaches $90 \%$ of the reference value with the addition of $5 \%$ of MFA, and reaches a value of $73,19 \%$ for an addition rate of $20 \%$ of MFA.

These mechanical measurements results show that the addition of unmilled or milled FA to industrial cement causes the decrease of the compressive strength at 28 days compared to reference cement. However, the milled FA cement mortars showed higher compressive strength than the unmilled ones. These findings correlate with the results of the study carried out by R. Kumar et al. [17], who found that the mechanical activation of the FA leads to a significant increase in the cement strength compared to cement blended with unmilled FA. According to the same study, the effect of mechanical activation depends on the type of activation device used; attrition mill, vibratory mill, etc.
The content of the amorphous phase of the fly ash, which reacts with $\mathrm{Ca}(\mathrm{OH})_{2}$ to produce C-S-H, increases with a prolonged grinding time. Therefore, the reactivity of milled fly ash is higher than that of the unmilled one [17], which explain the increase in compressive strength.

The milling is performed to improve the reactivity of the FA by reducing the size of the particles and creating new surfaces that serve as precipitation sites for cement hydration products, which is called the "filler effect" [17, 27]. This effect ensures a better distribution of the hydration products in the first days [32].

\section{Conclusions}

The main conclusions that can be derived from this study are presented as follows:

- The XRF analysis results showed that the mechanical activation of fly ash yielded an increase in the content of sicila, alumina and iron, while the amount of calcium oxide was reduced in both the milled fly ash, and the prepared mortars containing different percentages of milled fly ash.

- The addition of both unmilled and milled fly ash did not have a significant influence on the strength of blended mortars.

- It was found that both unmilled and milled fly ash cement mortars exhibited a decrease in the compressive strength in comparison with the reference at 28 days of curing, due to the fact that we used a class F fly ash, known for being a slow reacting pozzolan, and it only starts to react noticeably after several weeks at the curing temperature we worked with $\left(20^{\circ} \mathrm{C}\right)$. This decrease is also a result of the dilution effect of the clinker, which is the essential reactive component of the cement.

- The addition of milled fly ash gave higher compressive strength than the addition of unmilled one as a result of the increase in the fly ash fineness and its reactive components.

- The amount of fly ash that can be incorporated in the cement is limited because of its slow pozzolanic reaction, we found that the optimum addition rate for unmilled and milled fly ash cement mortars was 5\%, and they reached a relative compressive strength of $88.75 \%$ and $90 \%$ respectively.

- The fineness of fly ash acts in the early ages of hydration, it is called "filler effect" while the reactive components act over the long term, thus compensating for the dilution effect.

- It can be concluded that the fly ash fineness effect on compressive strength depends mainly on two parameters; the grinding time and the second parameter is the grinding device used.

\section{References}

1. M. Arezoumandi, J. S. Volz, C. A. Ortega, J. J. Myers. Materials and Design 46, 301-309 (2013). 
2. M. Ba-Shammakh, H. Caruso, A. Elkamel, E. Croiset, P. L. Douglas. American Journal of Environmental Sciences 4 (5), $482-490$ (2008).

3. A. M. Rashad. International Journal of Sustainable Built Environment 4, 278-306 (2015).

4. M. Ahmaruzzaman, Prog. Energy Combust. 36, 327363 (2010).

5. R. Kumar, S. Kumar, S.P. Mehrotra, Resources Conservation and Recycling 52 (2), 157-179 (2007).

6. A. Upadhyay, M. Kamal, Characterization and utilization of fly ash. (National Institute of Technology Rourkela, Orissa, 2007)

7. A. A. Ramezanianpour, Cement Replacement Materials (Springer Geochemistry/Mineralogy, Springer-Verlag Berlin Heidelberg, 2014).

8. Lerm info $\mathrm{n}^{\circ} 26$ : Fly ashes. http://doc.lerm.fr/lerminfo-n-26-les-cendres-volantes/ (Accessed 05/03/2017)

9. R.C. Joshi, R.P. Lohtia, Fly Ash in Concrete: Production, Properties and Uses (CRC Press, 1997).

10. Z.T. Yao, X.S. Ji, P.K. Sarker, J.H. Tang, L.Q. Ge, M.S. Xia, Y. Q. Xi, Earth-Sci. Rev. 141, 105121(2015).

11. M. Thomas, Optimizing the use of fly ash in concrete (Portland cement association report, 2007).

12. M. Narmluk, T. Nawa, Int. J. Chem. Eng. Appl. 5 (1), 31-35 (2014).

13. S. Goni, M. Frias, I. Vegas, R. Garcia, R.V. de la Villa, Cem. Concr. Compos. 34, 911-916 (2012).

14. R. Hamzaoui, O. Bouchenafa, S. Guessasma, N. Leklou, A. Bouaziz. Materials and Design 90, 29-37 (2016).

15. V. M. Malhotra, P. K. Mehta, High-Performance, High-Volume Fly-Ash Concrete: Materials, Mixture Proportioning, Properties, Construction practice and Case Histories, (Supplementary Cementing Materials for Sustainable Development Inc, 2002).

16. K.S. Wang, K.L. Lin, B.Y. Tzeng, J. Air Waste Manage. Assoc. 53, 1340-1346 (2003).

17. M.G. Li, C.J. Sun, S.H. Gau, C.J. Chuang, J. Hazard. Mater. 174, 586-591 (2010).

18. C.G. Chen, C.J. Sun, S.H. Gau, C.W. Wu, Y.L. Chen, Waste Manag. 33, 858-865 (2013).

19. Y. Kocak, S. Nas, Constr. Build. Mater. 73, 25-32 (2014)

20. L. Krishnaraj, P.T. Ravichandiran, R. Annadurai, P.R. Kannan Rajkumar, Int. J. ChemTech. Res. 7 (2), 555-563 (2014-2015).

21. ASTMC618-78: Specification of fly ash and raw or calcined natural pozzolan for use as a mineral admixture in Portland cement concrete, ASTM, Philadelphia, (1978).

22. S. Diamond, Cem. Conc. Res, 13, 459-464(1983).

23. K. Nabih, A. Quaboul, A. Hamadi, MATEC Web of conferences 2, 01010 (2012).

24. I. Elkhadiri, A. Diouri, A. Boukhari, J. Aride, F. Puertas, Cem. Conc. Res. 32, 1597-1603 (2002).

25. K. Nabih, M.K. Kada, M. Hmiri, N. Hamsi. MATEC Web of conferences 11, 01012 (2014).

26. K. De Weerdt, H. Justnes, K. O. Kjellsen. E. J. Sellevold, Nordic Concrete Research, 42 (2), 51-70 (2010).
27. K. De Weerdt, E. J. Sellevold, K. O. Kjellsen, H. Justnes, Advances in Cement Research. 23 (4), 203214 (2011).

28. J. Payá, J. Monzó, M.V. Borrachero, E. Peris-Mora, F. Amahjour, Cem. Conc. Res. 30, 543 - 551(2000).

29. A.A. Zaldívar-Cadena, I. Díaz-Peña, J.R. GonzálezLópez, F. Vázquez-Acosta, A. Cruz-López, O. Vázquez-Cuchillo, F. Vázquez-Rodríguez, L.M. Serrato-Arias, Adv. Mat. Res. 787, 286-290, (2013).

30. S. Aydın, Ç. Karatay, B. Baradan, Powder Tech. 197, 68-72 (2010).

31. M. Georgescu, N. Saca, U.P.B. Sci. Bull., Series B. 71 (3), 11-22 (2009)

32. K. De Weerdt, M. Ben Haha, G. Le Saout, K.O. Kjellsen, H. Justnes, B. Lothenbach.. Mat. and Struc., 45, 1101-1114(2012). 